\title{
Profil Kemampuan Argumentasi Siswa Mengenai Isu Sosiosaintifik dalam Pembelajaran Online
}

\author{
Rifda Tanfiziyah, Diana Rochintaniawati \\ Pendidikan Biologi, Fakultas Matematika dan IPA, Universitas Pendidikan Indonesia \\ Jl. Dr. Setiabudhni No.229, Cidadap, Isola, Sukasari, Kota Bandung, Jawa Barat 40154-Indonesia \\ e-mail: rifdatanfiziyah@upi.edu
}

\begin{abstract}
Abstrak
Kemampuan argumentasi penting untuk dikembangkan karena dapat melatih berpikir secara ilmiah, berkomunikasi dan bertindak seperti ilmuan. Penelitian ini bertujuan untuk mengetahui gambaran kemampuan argumentasi siswa pada pembelajaran biologi khususnya mengenai isu sosiosaintifik Jenis penelitian yang digunakan yakni penelitian deskriptif kuantitatif dengan metode observasi. Teknik pengambilan sampel menggunakan snow ball sampling. Instrumen yang digunakan menggunakan tes berupa essay dan angket. Hasil penelitian menunjukkan bahwa kemampuan argumentasi siswa menggunakan claim ketika berargumentasi (68\%), didukung oleh data (28\%), backing (10\%), qualifier (5\%) sedang presentase kemunculan warrant dan rebuttal (0\%). Dapat diketahui bahwa kemampuan argumentasi siswa paling tinggi berada pada level 3 dengan dominasi pendukung claim terbanyak yaitu data/konsep ilimah dan pengalaman maupun pengamatan pribadi terhadap lingkungan.
\end{abstract}

Kata Kunci-Isu Sosiosaintifik, Kemampuan Argumentasi, Pembelajaran Online

\begin{abstract}
Argumentation skills are important to develop because they can train to think scientifically, communicate and act like scientists. This study aims to describe the student's argumentative ability in biology learning, especially regarding socio-scientific issues. The type of research used is descriptive quantitative research with the observation method. The sampling technique used snow ball sampling. The instruments used are tests in the form of essays and questionnaires. The results showed that the argumentation ability of students using claims when arguing (68\%), supported by data (28\%), backing $(10 \%)$, qualifiers $(5 \%)$ was the percentage of warrants and rebuttals $(0 \%)$. It can be seen that the highest students' argumentation ability is at level 3 with the support of claims, namely scientific data/concepts and experiences as well as personal observations of the environment.
\end{abstract}

Keywords - Socio-scientific Issues, Argumentation Skills, Online Learning

\section{PENDAHULUAN}

Abad 21 yang dicirikan oleh berkembangnya informasi secara digital. Hal inilah yang dikatakan oleh banyak orang dengan revolusi industri, terutama industri informasi. Era digital inilah yang mewarnai kehidupan manusia di abad 21 (Syahputra, 2018). Pembelajaran di abad 21 harus dapat mempersiapkan generasi manusia menyongsong kemajuan teknologi informasi dan komunikasi kehidupan bermasyarakat (Iman dkk., 2019). Maka dari itu, kualitas pendidikan harus ditingkatkan (Septikasari \& Frasandy,
2018). Penyediaan pendidikan sains yang berkualitas akan berdampak pada ketercapaian pembangunan suatu negara. Pendidikan sains bergantung pada pembelajaran yang digunakan di setiap negara. Melalui pendidikan sains, siswa dapat terlibat pada dampak sains dalam kehidupan sehari - hari dan peran siswa dalam masyarakat. Dengan menerapkan konsep sains dalam pendidikan sains, siswa Indonesia diharapkan mampu menyelesaikan permasalahan di kehidupan nyata pada era abad 21 ini (Pratiwi dkk., 2019). 
Melalui pembelajaran sains siswa diharapkan dapat mengembangkan pengetahuan, sikap dan proses untuk mencapai tujuan pendikan nasional. Terdapat beberapa cara untuk mengembangkan sains, salah satunya melalui keterampilan argumentasi (Sadler dan Zeidler, 2005); (Tekin dkk., 2020). Menurut Setiono (2017) proses pembelajaran sains harus dapat memicu keterampilan tingkat tinggi (berpikir kritis, kreatif, dan memiliki kemampuan pemecahan masalah) pada siswa. Keterampilan argumentasi merupakan salah satu penentu keberhasilan siswa dalam pembelajaran karena berkaitan dengan kemampuan seseorang dalam pengambilan keputusan terbaik dalam menghadapi pemecahan masalah.

Untuk mempelajari ilmu alam seperti biologi, maka kemampuan argumentasi ini dapat menjadi sarana penting dalam mendorong siswa dalam berpikir kritis (Viyanti dkk., 2016). Kemampuan berargumentasi merupakan hal utama yang mendasari siswa dalam belajar bagaimana berpikir, bertindak dan berkomunikasi secara ilmiah (Erduran dkk., 2004). Misalnya, pada saat berdiskusi seorang siswa mungkin memiliki penjelasan yang sama atau berbeda dengan siswa lainnya. Mereka mengajukan penjelasan masing-masing disertai dengan alasan dan bukti yang mereka miliki. Dari penjelasan terebut, maka rasionalitas sains dapat terlihat pada kemampuan untuk membangun argumen Ryang mengajak dan meyakinkan pembaca mengenai apa yang diajukannya. Oleh karena itu, karakteristik kunci dalam penalaran ilmiah adalah argumentasi Duschl and Osborne (2002); Yang \& Tsai (2010).

Dalam hal ini, argumen dapat digunakan untuk memberikan alasan mengenai masalah yang menantang. Kemampuan argumentasi sangat penting dalam kehidupan sehari-hari karena argumentasi tersebut berperan dalam membuat keputusan yang benar dan logis mengenai isu yang bersifat kontroversial (Yang \& Tsai, 2010). Isu sosio-saintifik merupakan isuisu yang berdasarkan pada masalah atau konsep ilmiah, bersifat kontroversial, didiskusikan di ruang publik dan biasanya memiliki pengaruh politik dan sosial Dawson \& Venville (2009); (Vera dkk., 2021). Ketika menghadapi isu sosiosaintifik, seorang siswa harus membuat keputusan tentang tindakan apa yang harus diambil atau apa yang harus disetujui tidak disetujui, dengan mengungkapkan bukti serta alasan yang dapat mendukung keputusannya. Sehingga saat siswa bernalar tentang isu sosiosaintifik, siswa dapat menunjukkan argumentasinya yang meliputi konstruksi argumen pendukung, counter-argumen, dan rebuttal (Sadler dan Zeidler, 2005); (Tekin dkk., 2020).

Pada Desember 2019, untuk pertama kalinya, Kota Wuhan di Tiongkok secara resmi mendeklarasikan kehadiran sebuah virus tidak dikenal (sekarang disebut COVID-19) yang segera memperoleh status pandemi, merenggut banyak nyawa Dunia. Virus ini sangat menyebar dengan cepat dan telah menyebar ke hampir semua negara, termasuk Indonesia dengan waktu yang cepat. Obat untuk mencegah COVID-19 belum ditemukan, yang menyebabkan lebih banyak orangterinfeksi dan sekarat. Ini menyebabkan pemerintah untuk mengadopsi kebijakan, salah satunya adalah kebijakan pembelajaran selama Covid-19 pandemi. Semua kegiatan pembelajaran pada semua jenjang pendidikan khususnya di perguruan tinggi mengalami transformasi, dimana pendidik tidak dapat secara langsung menginstruksikan pembelajaran dan dialihkan ke media virtual, sedangkan penugasan dan evaluasi pembelajaran dilakukan melalui pembelajaran online. (Budiyono Saputro dkk., 2020). Dalam masyakarat maju, ini bukanlah hal baru. Namun sudah menjadi bagian dari kurikulum siswa pada umumnya yang sudah akrab dengan pembelajaran online (Kimkong Heng \& Koemhong Sol, 2020). Oleh karenanya penelitian ini bertujuan untuk melihat pembelajaran yang dilakukan secara online tetap efektif dilakukan untuk mengembangkan keterampilan siswa. Penelitian ini bertujuan untuk mengetahui profil keterampilan scientific reasoning siswa yang dilihat melaui kemampuan argumentasi siswa yang dilaksanakan secara online.

\section{METODE PENELITIAN}

Penelitian ini menggunakan metode deskriptif kuantitatif yang bertujuan untuk menggambarkan kemampuan argumentasi siswa mengenai isu sosiosaintifik biologi dalam kondisi alami tanpa adanya perlakuan. Dalam kegiatan belajar mengajar yang terjadi di sekolah 
penelitian, perencanaan pembelajarannya diserahkan sepenuhnya kepada guru mata pembelajaran tanpa ada intervensi dari peneliti. Penelitian ini dilakukan dengan mengamati

Tabel 1. Rubrik tingkat komponen argumen siswa

\begin{tabular}{ll}
\hline Level & Deskripsi \\
\hline 1 & Hanya mengandung claim \\
2 & $\begin{array}{l}\text { Mengandung claim dan data, dan atau terdapat } \\
\text { warrant }\end{array}$ \\
3 & $\begin{array}{l}\text { Mengandung claim dan data, warrant dan } \\
\text { backing qualifier/backing/rebuttal } \\
\text { Mengandung claim dan data, warrant, backing } \\
\text { qualifier dan backing/rebuttal } \\
\text { Mengandung claim dan data, warrant, backing } \\
\text { qualifier, backing dan rebuttal }\end{array}$ \\
\hline
\end{tabular}

pembelajaran yang dilakukan secara online. Subjek dalam penelitian ini merupakan siswa SMA kelas XI di salah satu sekolah di Banten.

Argumentasi ilmiah siswa dijaring melalui instrumen essay tentang isu sosiosaintifik. Analisis argumentasi ilmiah siswa dilakukan melalui argumen siswa pada aspek jenis claim yang diajukan, dasar pengajuan claim, serta kekuatan komponen argumen siswa (Tabel 1). Banyaknya argumen siswa untuk setiap level argumen yang diberikan dihitung dalam bentuk persen menggunakan rumus yang dikemukakan oleh Purwanto (2013) sebagai berikut:

$$
N P=\frac{R}{S M} \times 100 \%
$$

Keterangan:

NP : Nilai persen yang dicari atau diharapkan

$\mathrm{R}$ : Skor mentah yang diperoleh (dalam penelitian ini: jumlah argumen yang muncul pada tingkat level yang ditentukan

SM : Skor maksimum ideal yang diharapkan (dalam penelitian ini: jumlah total argumen siswa di kelas yang ditentukan).

Selain instrumen essay, diberikan angket untuk menjaring pendapat siswa mengenai pertanyaan guru terkait pengembangan keterampilan argumentasi siswa. Selain itu, digunakan juga lembar observasi yang bertujuan untuk mengamati aktivitas yang digunakan oleh guru, siswa, serta interaksi antara guru dan siswa maupun siswa dengan siswa lainnya selama proses pembelajaran biologi. Posisi peneliti dalam observasi ini sebagai non-partisipan, berada di luar kelompok yang diteliti, sehingga peneliti hanya melihat dan membuat catatan lapangan tanpa terlibat langsung dengan aktivitas yang dilakukan oleh siswa. Lembar observasi ini berbentuk format isian, dimana peneliti menuliskan catatan deskriptif mengenai aktivitas guru dan siswa selama kegiatan berlangsung.

\section{HASIL DAN PEMBAHASAN}

Keterampilan argumentasi adalah kemampuan siswa untuk menarik kesimpulan sebagai sebuah keputusan dari informasi yang tersedia dengan berdasarkan fakta. Toulmin menyebutkan bahwa argumentasi terdiri beberapa komponen yaitu klaim (claim), data (data), pembenaran (warrant), dukungan (backing), kualifikasi (qualifier) dan sanggahan (rebuttal) (Cetin, 2014). Data hasil pengamatan pada Gambar 1 menunjukkan kemampuan argumentasi siswa menggunakan claim ketika berargumentasi (68\%), didukung oleh data (28\%), backing (10\%), qualifier (5\%) sedang presentase kemunculan warrant dan rebuttal $(0 \%)$. Argumentasi ilmiah siswa diidentifikasi melalui argumen yang diajukan oleh siswa mengenai 3 permasalah isu sosiosaintifik terkait rekayasa genetika, sistem pencernaan dan sistem pernafasan.

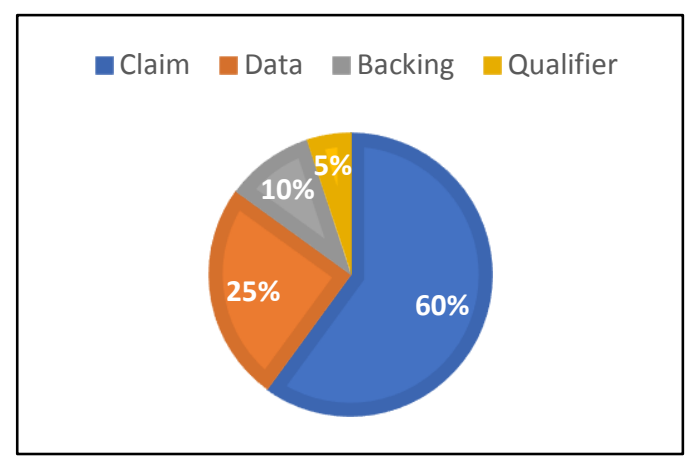

Gambar 1. Presentase unsur argumentasi siswa mengenai isu sosiosaintifik 
Tabel 2. Claim tentang pemberian MSG kepada anak

\begin{tabular}{ll}
\hline \multicolumn{1}{c}{ Jenis Claim } & \multicolumn{1}{c}{ Contoh claim } \\
$\begin{array}{l}\text { Rasa dan tekstur } \\
\text { yang disukai } \\
\text { (setuju) }\end{array}$ & $\begin{array}{l}\text { Menurut saya memang banyak ibu-ibu yang memberikan junk food kepada anak-anaknya, agar anak mereka mau makan. } \\
\text { karena tidak bisa dipungkiri bahwa makanan tersebut memiliki rasa dan tekstur yang enak sehingga membuat ketagihan }\end{array}$ \\
\hline $\begin{array}{l}\text { Kandungan MSG } \\
\text { (setuju dengan } \\
\text { catatan) }\end{array}$ & $\begin{array}{l}\text { Menambahkan MSG dapat meningkatkan nafsu makan anak. Ditambah lagi, mineral yang terkandung pada micin } \\
\text { dibutuhkan untuk menunjang kerja dan fungsi organ tubuhnya. MSG terbilang aman jika dikonsumsi dalam batas aman } \\
\text { dan kebutuhan hariannya. Sebaliknya, apabila dimakan terlalu sering dan banyak, kadar natrium dalam tubuh jadi } \\
\text { meningkat dan dapat menimbulkan masalah kesehatan. }\end{array}$ \\
\hline $\begin{array}{l}\text { Tinjauan Kesehatan } \\
\text { (tidak setuju) }\end{array}$ & Menurut saya seharusnya ibu tidak memberikan junk food pada anak karena kurang baik untuk kesehatan \\
\hline
\end{tabular}

Tabel 3. Argunen siswa terhadap claim pemberian MSG pada anak

\begin{tabular}{|c|c|c|c|c|}
\hline No & Kriteria & Contoh claim & Total & $\%$ \\
\hline 1 & Claim didasari data & $\begin{array}{l}\text { Banyak produk nugget dan sosis yang tidak mengandung MSG, tetapi menurut } \\
\text { detikhealth, yang dikhawatirkan dari produk-produk tersebut justru kandungan } \\
\text { nutrisinya yang kurang. Meskipun begitu, nugget, sosis, atau ayam goreng dapat } \\
\text { meningkatkan selera makan anak, karena dapat dibuat menjadi karakter-karakter lucu } \\
\text { yang dapat menarik perhatian anak. }\end{array}$ & 3 & $\begin{array}{l}13,04 \\
\%\end{array}$ \\
\hline \multirow[t]{2}{*}{2} & \multirow[t]{2}{*}{$\begin{array}{l}\text { Claim didasari data } \\
\text { dan qualifier }\end{array}$} & $\begin{array}{l}\text { Dilansir dari Healthy Kids, Selasa (31/3), dikatakan bahwa anak tidak boleh sering } \\
\text { sering mengonsumsi fast food, Dan bila anak diberikan bekal makan Seperti } \\
\text { nugget sebaiknya perlu diberikan sayur Dan air putih }\end{array}$ & 1 & \multirow[t]{2}{*}{$\begin{array}{l}13,04 \\
\%\end{array}$} \\
\hline & & $\begin{array}{l}\text { Ibu-ibu yang menyediakan nughet, sosis dan ayam dalam menu makan agar anaknya } \\
\text { mau makan merupakan tindakan yang cukup baik asalkan di tambah dengan sayuran } \\
\text { agar komposisi nutrisinya lebih lengkap karena nughet, sosis dan ayam mengandung } \\
\text { karbohidrat, protein dam lemak (data). }\end{array}$ & 2 & \\
\hline \multirow[t]{2}{*}{3} & \multirow[t]{2}{*}{$\begin{array}{l}\text { Claim didasari } \\
\text { pengalaman/penga } \\
\text { matan pribadi }\end{array}$} & $\begin{array}{l}\text { Banyak sekali ibu2 yg merasa stres jika anaknya tidak mau makan sama sekali, jadi ibu } \\
\text { lebih memilih memberikan makanan junk food yg rasanya lebih disukai anak } 2 \\
\text { meskipun tidak baik jika diberikan terus menerus. }\end{array}$ & 5 & \multirow[t]{2}{*}{$39,1 \%$} \\
\hline & & Buktinya adalah banyak ibu-ibu lebuh memilih beli nugget karena praktis. & 4 & \\
\hline 4 & $\begin{array}{l}\text { Claim didasari data } \\
\text { dan pengalaman } \\
\text { pribadi }\end{array}$ & $\begin{array}{l}\text { dapat diketahui juga, sekarang sudah banyak orang tua yang membeli nugget, sosis } \\
\text { untuk anak2nya sebagai persedian makanan salah satunya sebagai menu bekal. Ibu saya } \\
\text { sering memberikan nugget dan sosis pada bekal makanan adik saya karena selain } \\
\text { kandungan gizi yg sudah dijelaskan juga praktis Lalu makanan2 tersebut juga } \\
\text { memiliki beberapa manfaat dan khasiat apabila dikonsumsi seperti dapat menambah } \\
\text { massa otot, dapat meningkatkan nafsu makan, meningkatkan sistem kekebalan tubuh } \\
\text { juga, bagus untuk pertumbuhan anak, dan lainnya. Dalam makanan ini dilengkapi } \\
\text { kandungan nutrisi seperti vitamin A, C, D, B6, B12, kalsium, fosfor, magnesium, } \\
\text { selenium, dan zat besi yang semuanya sangat berperan penting. }\end{array}$ & 6 & $\begin{array}{l}26,08 \\
\%\end{array}$ \\
\hline
\end{tabular}

Claim, dasar pengajuan claim serta kekuatan argumen siswa tentang pemberian makanan instan yang mengandung $M S G$ pada anak

Pertanyaan pertama menanyakan tentang dampak yang akan terjadi apabila orang tua memberikan nuget/sosis/makanan siap saji pada anak mereka padahal di dalam makanan siap saji tersebut mengandung MSG. Berdasarkan claim siswa diperoleh yang mengungkapkan: 1) ungkapan setuju karena tidak bisa dipungkiri bahwa makanan tersebut memiliki rasa dan tekstur yang enak sehingga membuat ketagihan dan menambah napsu makan anak, 2) ungkapan setuju namun dengan memberikan catatan dampak dari konsumsi makanan siap saji, dan 3) ungkapan tidak setuju karena alasan kesehatan (Tabel 2).
Berdasarkan tabel tersebut, diungkapkan bahwa terdapat variasi dari claim yang diajukan siswa. Namun sebagian besar menyetujui pemberian makanan siap saji pada anak namun dengan catatan bahwa pemberian tidak terlalu sering, kemudian perlu ditambah serat berupa sayur yang cukup agar kebutuhan gizi tetap terpenuhi. Sebagian siswa memberikan data dari dampak yang ditimbulkan terhadap konsumsi makanan cepat saji. Sebagian siswa lainnya memberikan pengalaman pribadinya dengan melihat kondisi di lapangan (Tabel 3). Selain adanya claim dan data, ada juga siswa yang tidak menyetujui pemberian makanan cepat saji kepada anak karena alasan kesehatan. Dalam mengajukan data pendukung claim sebanyak 43,4\% $(\mathrm{n}=10)$ siswa memiliki data yang kuat sehingga bisa memperkuat claim yang diajukan. Dalam hal ini, pada umumnya siswa bernalar menggunakan konsep yang mereka ketahui tentang dampak dari konsumsi MSG terhadap 
kesehatan tubuh. Meskipun sebagian lainnya (56,6\%) mereka mengemukakan data (konsep/ akta) yang berasal dari pengalaman pribadi yang mereka lihat di lingkungan masing-masing.

Claim, dasar pengajuan claim serta kekuatan argumen siswa tentang konsumsi tomat yang diubah secara genetik

Pertanyaan kedua meminta siswa untuk mengungkapkan alasan mengenai konsumsi tomat yang diubah secara genetic. Claim yang diajukan siswa terhadap masalah ini (Tabel 4) menyatakan bahwa konsumsi makanan yang diubah secara genetik, 1) tidak setuju karena bisa aman bagi kesehatan apabila dikonsumsi terus menerus, 2) Setuju dengan catatan, ada baik buruknya dalam pengkonsumsian tomat ini, bisa meningkatkan perekonomian namun jika dikonsumsi terus menerus akan memberi efek buruk terhadap tubuh, 3) Setuju karena rekayasa genetik tidak memberikan efek serius terhadap tubuh.
Claim siswa sangat bervariasi, banyak data yang diberikan untuk memperkuat argumen akibat atau efek samping dari konsumsi tomat yang diubah secara rekayasa genetika terhadap tubuh. Ada juga yang memberikan backing mengenai kandungan yang terdapat pada tomat yang diubah secara genetik dan didukung oleh data yang ditemukan (Tabel 5).

Claim, dasar pengajuan claim serta kekuatan argumen siswa tentang konsumsi rokok pada lansia

Pertanyaan ketiga meminta pendapat siswa mengenai konsumsi rokok pada lansia. Claim yang diajukan siswa (Tabel 6) sangat bervariasi namun banyaknya siswa yang mengajukan claim didasarkan dengan pengamatan pribadi masingmasing $(n=14)$. Ada juga beberapa siswa yang menggunakan data sebagai penguatan dari claim yang diajukan $(n=3)$. Sebagaian lainnya hanya mengajukan claim saja $(n=5)$.

Tabel 4. Claim tentang konsumsi tomat yang diubah secara genetic

\begin{tabular}{ll}
\hline Jenis Claim & Contoh claim \\
\hline Tidak setuju & apabila itu diubah secara Kimiawi dengan senyawa tidak aman, maka tidak baik untuk dikonsumsi secara terus-menerus \\
\hline $\begin{array}{l}\text { Setuju dengan } \\
\text { catatan }\end{array}$ & $\begin{array}{l}\text { menurut beberapa artikel yang saya baca, disebutkan bahwa memang ada baik dan buruknya dari pemberlakuan hasil } \\
\text { tani transgenik, salah satunya pada tomat yaitu tomat Flavr Savr, baiknya meningkatkan perekonomian karena tidak } \\
\text { cepat busuk, buruknya jika dikonsumsi terus menerus dalam jangka waktu panjang dapat meningkatkan potensi } \\
\text { toksisitas bahan pangan, berpotensi menimbulkan keluhan alergi, gatal", ruam pada permukaan kulit hingga kulit } \\
\text { bersisik, serta dapat menggangu keseimbangan ekosistem akibat musnahnya plasma nutfah yang asli }\end{array}$ \\
\hline Setuju & Rekayasa genetik tidak memberikan efek yg terlalu serius selama dilakukan dengan baik \\
& $\begin{array}{l}\text { menurut saya (yang bukan seorang pakar gizi atau kesehatan) makanan yang menggunakan perubahan genetik itu sudah } \\
\text { banyak. dan banyak pula yang bisa memberikan manfaat lebih kepada konsumen. menurut saya tidak apa-apa jika } \\
\text { tomat tersebut dikonsumsi secara terus-menerus karena inovasi genetik bukanlah hal yang berbahaya. tetapi memang } \\
\text { diciptakan untuk menambah kualitas makanan tersebut. jadi menurut saya tidak salah, kalau kita ingin mengonsumsi } \\
\text { makanan tersebut secara terus menerus }\end{array}$ \\
\hline
\end{tabular}


Tabel 5. Argunen siswa terhadap claim pengkonsumsian tomat yang diubah secara genetik

\begin{tabular}{|c|c|c|c|c|}
\hline No & Kriteria & Contoh claim & Total & $\%$ \\
\hline \multirow[t]{2}{*}{1.} & \multirow[t]{2}{*}{$\begin{array}{l}\text { Claim } \\
\text { didasari } \\
\text { data }\end{array}$} & $\begin{array}{l}\text { menurut beberapa artikel yang saya baca, disebutkan bahwa memang ada baik dan buruknya } \\
\text { dari pemberlakuan hasil tani transgenic (claim), salah satunya pada tomat yaitu tomat Flavr } \\
\text { Savr, jika dikonsumsi terus menerus dalam janhka waktu panjang dapat meningkatkan } \\
\text { potensi toksisitas bahan pangan, berpotensi menimbulkan keluhan alergi, gatal", ruam pada } \\
\text { permukaan kulit hingga kulit bersisik, serta dapat menggangu keseimbangan ekosistem } \\
\text { akibat musnahnya plasma nutfah yang asli. Dan pada tahun 1996, WHO menyatakan bahwa } \\
\text { munculnya berbagai jenis bahan kimia baru, baik dalam organisme transgenik maupun } \\
\text { prosuknya yang dapat menimbulkan penyakit baru atau menjadi salah satu faktor yang } \\
\text { memicu penyakit lainnya (data). }\end{array}$ & 10 & \multirow[t]{2}{*}{$69,5 \%$} \\
\hline & & $\begin{array}{l}\text { Dilansir Dari ruangguru.com mengonsumsi terlalu banyak Tomat Flavr Savr Akan } \\
\text { menyebabkan alergi pada tubuh (data) }\end{array}$ & 7 & \\
\hline \multirow[t]{2}{*}{2} & \multirow{2}{*}{$\begin{array}{l}\text { Claim } \\
\text { didukung } \\
\text { data dan } \\
\text { backing }\end{array}$} & $\begin{array}{l}\text { Tomat flavr savr jika dikonsumsi dalam jangka lama dapat menyebabkan alergi, gatal-gatal, } \\
\text { ruam pada kulit, dan kulit bersisik (data). Hal ini dimungkinkan karena adanya perubahan } \\
\text { genetik dalam buah tomat tersebut (backing). }\end{array}$ & 3 & \multirow[t]{2}{*}{$21,7 \%$} \\
\hline & & $\begin{array}{l}\text { Berdasarkan penelitian, konsumsi tomat Flavr Savr dapat menimbulkan alergi dan } \\
\text { menyebabkan resistensi terhadap antibiotik dalam tubuh (data). Karena mengandung protein } \\
\text { yang toksik (backing). }\end{array}$ & 2 & \\
\hline 3. & $\begin{array}{l}\text { Hanya } \\
\text { claim }\end{array}$ & $\begin{array}{l}\text { Tidak ada dampak yang terjadi karena perubahannya secara genetik dan tidak menggunakan } \\
\text { pegawet }\end{array}$ & 1 & $4,34 \%$ \\
\hline
\end{tabular}

Tabel 6. Argunen siswa terhadap claim konsumsi rokok pada lansia

\begin{tabular}{|c|c|c|c|c|}
\hline No & Kriteria & Contoh claim & Total & $\%$ \\
\hline \multirow[t]{4}{*}{1.} & $\begin{array}{l}\text { Claim } \\
\text { disertai } \\
\text { pengalam } \\
\text { an/penga } \\
\text { matan }\end{array}$ & $\begin{array}{l}\text { menurut saya lansia yang tidak berhenti merokok karena sudah 'terlanjur', ada alasan lainnya } \\
\text { seperti ingin cepat meninggal, atau sudah kecanduan dari remaja misalnya, atau buat adiksi } \\
\text { kesenangan semata. lihatlah di perkampungan / pedesaan Jawa. Banyak yang sudah merokok } \\
\text { bahkan di warung-warung banyak menyediakan bungkusan rokok. Alhasil banyak yang } \\
\text { mengonsumsi rokok hingga lansia }\end{array}$ & 3 & $60,8 \%$ \\
\hline & pribadi & $\begin{array}{l}\text { Kebiasaan merokok pada lansia memang cukup sulit untuk dihentikan karena faktor usia yang } \\
\text { menjadikan seseorang keras kepala, faktor pengalaman yang ternyata rokok tidak seburuk yang } \\
\text { diberitakan, dan faktor kebiasaan (claim) Ayah saya yang susah di berhenti merokok walau } \\
\text { sudah tau bahaya dan dampak rokok pada tubuhnya. }\end{array}$ & 3 & \\
\hline & & $\begin{array}{l}\text { Roko menjadi sangat candu bagi penggunanya, apalagi sudah merokok dalam jangka waktu yg } \\
\text { sangat lama akan menjadi susah jika dipaksa untuk tidak merokok karena sudah ketergantungan } \\
\text { walaupun perokok aktif tau bahaya dan dampak dari merokok (claim). Disekitar saya banyak } \\
\text { sekali perokok aktif yg sudah merokok dalam jangka waktu yg sangat lama, namun tidak bisa } \\
\text { berhenti untuk merokok karena sudah ketergantungan terhadap rokok }\end{array}$ & 3 & \\
\hline & & $\begin{array}{l}\text { Saya tidak setuju umur berapa pun yang merokok (claim). Banyak sekali kerabat saya yang } \\
\text { merokok lama kelamaan organ tubuh menjadi rusak dan tidak berfungsi. }\end{array}$ & 5 & \\
\hline 2. & $\begin{array}{l}\text { Claim } \\
\text { didukung } \\
\text { data }\end{array}$ & $\begin{array}{l}\text { Kebiasaan orang tua yg sulit berhenti merokok itu disebabkan karena pada saat mudanya ia } \\
\text { menjadi perokok akut, dan hal tersebut akan berdampak kepada kesehatan tubuhnya di beberapa } \\
\text { puluh tahun ke depan (claim). Berdasarkan penelitian yang sudah banyak dilakukan, bahan- } \\
\text { bahan kimia pada rokok berpotensi merusak sel paru-paru yang kemudian bisa berubah menjadi } \\
\text { sel kanker. Selain itu, merokok juga bisa menyebabkan terjadinya berbagai penyakit pada paru- } \\
\text { paru, seperti bronkitis, penyakit paru obstruktif kronis (PPOK), dan emfisema (data). }\end{array}$ & 3 & $\begin{array}{l}13,04 \\
\%\end{array}$ \\
\hline 3 & $\begin{array}{l}\text { Hanya } \\
\text { claim saja }\end{array}$ & $\begin{array}{l}\text { Merokok sebagai kebiasaan yang buruk sudah sangat awam bagi masyarakat luas. Bagi orang } \\
\text { tua yang sulit untuk berhenti merokok menurut saya sangat disayangkan mengingat dampak } \\
\text { buruk bagi kesehatan itu sendiri dan dapat juga berpengaruh bagi keluarganya terutama anak- } \\
\text { anaknya (bagi yang sudah berkeluarga). Menurut saya, merokok merupakan preferensi pribadi, } \\
\text { tetapi juga menimbulkan dampak buruk bagi orang-orang sekitar (perokok pasif). Saya sangat } \\
\text { setuju jika orang-orang tua berhenti merokok dengan langkah-langkah yang kecil maupun } \\
\text { melalui lembaga-lembaga yang mengurusi gerakan berhenti merokok (claim). }\end{array}$ & 5 & $21,7 \%$ \\
\hline
\end{tabular}




\section{Pembahasan}

Saintis selalu menggunakan argumen untuk mendukung claim yang mereka ajukan melalui penggunaan warrants dan backings serta keterkaitannya dengan bukti yang dimiliki. Siswa sains perlu mempelajari proses argumentasi, karena rasionalitas sains dijelaskan untuk membangun argumen yang perusasif dan meyakinkan, serta berhubungan dengan penjelasan teori terhadap data hasil observasi (Erduran dkk., 2004); (Herawati dkk., 2015). Berdasarkan hasil penelitian, diperoleh bahwa pada umumnya siswa menggunakan fakta/ konsep ilmiah sebagai dasar pengajuan claim. Hal ini menunjukkan bahwa pemahaman siswa berperan terhadap claim yang diajukan. Beberapa siswa yang memiliki pemahaman konsep baik, kemampuan argumentasinya juga cukup baik (ditinjau dari cara siswa mengajukan claim). Sesuai dengan penelitian yang dilakukan oleh Cetin (2014) bahwa pemahaman konsep siswa sangat berperan dalam memfasilitasi kemampuan argumentasi siswa.

Dasar pengajuan claim kedua yang sering muncul yaitu claim yang didasarkan oleh pengamatan/pengalaman mereka dalam kehidupan (seperti lokasi tempat tinggal, apa yang mereka lihat dan dengar, kegiatan yang pernah dilakukan). Kebiasaan berargumentasi dapat diterapkan dalam kehidupan sehari-hari maka, guru bisa mempersiapkan kegiatan pembelajaran yang memicu siswa belajar misalnya inkuiri karena penalaran ilmiah dapat dikembangkan melalui latihan (Herawati dkk., 2015). Berdasarkan hasil temuan, pada beberapa materi guru menggunakan metode diskusi yang merangsang siswa untuk mengemukakan pendapatnya namun kurang muncul diskusi antar siswa sehingga lebih banyaknya guru melaksanakan metode tanya jawab dibandingkan kegiatan diskusi siswa. Metode tanya jawab sebenarnya memiliki manfaat yang positif karena dapat menarik dan memusatkan perhatian siswa. Dengan mengajukan pertanyaan yang terarah, siswa akan tertarik dalam mengembangkan daya piker sehingga kemampuan berpikir siswa dan keruntutan dalam mengemukakan pokok-pokok pikirannya dapat terdeteksi ketika menjawab pertanyaan (Herawati dkk., 2015). Hanya saja, keberhasilan metode tanya jawab dalam mengembangkan daya pikir siswa ditentukan oleh kualitas pertanyaan yang diberikan guru. Sehingga seorang guru harus menyiapkan pertanyaan yang merangsang kemampuan berpikir siswa, khususnya kemampuan argumentasi.

\section{KESIMPULAN}

Keterampilan argumentasi adalah kemampuan siswa untuk menarik kesimpulan sebagai sebuah keputusan dari informasi yang tersedia dengan berdasarkan fakta. Ketika dihadapkan pada masalah terkait isu sosiosaintifik siswa mengajukan claim berdasarkan data, konsep/ fakta ilmiah, pengalaman dan juga opini/dugaan. Secara umum, dari hasil pengamatan pembelajaran yang dilakukan secara online sebagian siswa sudah memiliki argumen yang cukup kuat dengan dibuktikan pendukung yang berupa data, warrant dan backing yang juga benar. Sehingga kemampuan argumentasi siswa bisa dikatakan paling tinggi berada pada level 3. Selain itu, kemunculan rebuttal dalam mendukung argumentasi tidak ditemukan dalam penelitian ini.

\section{DAFTAR PUSTAKA}

Budiyono Saputro, Muh Saerozi, \& Fadhil Ardhiansyah. (2020). Philosophical Reflections: Critical Analysis of Learning Strategies for Science Practicum During the COVID-19 Pandemic. IJORER : International Journal of Recent Educational Research, 1(2), 78-89. https://doi.org/10.46245/ijorer.v1i2.26

Cetin, P. S. (2014). Explicit argumentation instruction to facilitate conceptual understanding and argumentation skills. Research in Science and Technological Education, 32(1), 1-20. https://doi.org/10.1080/02635143.2013.850 071

Herawati, D., Widodo, A., Riandi, \& Rochintaniawati, D. (2015). Penalaran Ilmiah Siswa Tentang Lingkungan dan Pemanasan Global. Prosiding Seminar 
Nasional IPA IV.

Iman, F., Faoji Anwar, I., Junita Harahap, L., Ningsih, S., Miarsyah, M., \& Hendi Ristanto, R. (2019). Pengembangan Media Pembelajaran Prezi Berbasis Mnemonic Pada Materi Klasifikasi Makhluk Hidup. BIOSFER : Jurnal Biologi Dan Pendidikan Biologi, 4(1). https://doi.org/10.23969/biosfer.v4i1.1356

Kimkong Heng, \& Koemhong Sol. (2020). Online learning during COVID-19: Key challenges and suggestions to enhance effectiveness. Cambodian Education Forum (CEF), December, 1-15. https://www.researchgate.net/publication/34 6719308_Online_learning_during_COVID19_Key_challenges_and_suggestions_to_en hance_effectiveness

Pratiwi, S. N., Cari, C., \& Aminah, N. S. (2019). Pembelajaran IPA Abad 21 dengan Literasi Sains Siswa. Jurnal Materi Dan Pembelajaran Fisika (JMPF), 9(1), 34-42. https://jurnal.uns.ac.id/jmpf/article/view/31 612

Purwanto, N. (2013). Prinsip-prinsip dan Teknik Evaluasi Pengajaran. PT Remaja Rosdakatya.

Septikasari, R., \& Frasandy, R. N. (2018). Keterampilan 4C Abad 21 dalam Pembelajaran Pendidikan Dasar. Tarbiyah Al-Awlad, VIII, 112-122.

Setiono, S. (2017). Optimalisasi Penguasaan Konsep, Kemampuan Berinkuiri Dan Sikap Ilmiah Mahasiswa Melalui Modul Berbasis Inkuiri. BIOSFER: Jurnal Biologi Dan Pendidikan Biologi, 1(1), 10-15. https://doi.org/10.23969/biosfer.v1i1.266

Sitohang, J. (2017). Penerapan Metode Tanya Jawab untuk Meningkatkan Hasil Belajar IPA Pada Siswa Sekolah Dasar. Suara Guru: Jurnal Ilmu Pendidikan Sosial, Sains, Dan Humaniora, 3(4), 681-688.

Syahputra, E. (2018). Pembelajaran Abad 21 Dan Penerapannya Di Indonesia. Prosiding Seminar Nasional SINASTEKMAPAN, l(March), 1276-1283. https://www.researchgate.net/publication/33 1638425_PEMBELAJARAN_ABAD_21_ DAN_PENERAPANNYA_DI_INDONESI A/link/5c847e51458515831f96f565/downlo $\mathrm{ad}$
Tekin, N., Aslan, O., \& Y1lmaz, S. (2020). Improving Pre-Service Science Teachers' Content Knowledge and Argumentation Quality through Socio-Scientific IssuesBased Modules: An Action Research Study. Journal of Science Learning, 4(1), 80-90. https://doi.org/10.17509/jsl.v4i1.23378

Vera, Anwar, Y., \& Ermayanti. (2021). The correlation between scientific argumentation with viruses learning outcomes of senior high school student. Biosfer: Jurnal Pendidikan Biologi, 14(1), 54-64.

Viyanti, V., Cari, C., Sunarno, W., \& Kun Prasetyo, Z. (2016). Pemberdayaan Keterampilan Argumentasi Mendorong Pemahaman Konsep Siswa. Jurnal Penelitian Pembelajaran Fisika, 7(1), 4348. https://doi.org/10.26877/jp2f.v7i1.1152

Yang, F. Y., \& Tsai, C. C. (2010). Reasoning about science-related uncertain issues and epistemological perspectives among children. Instructional Science, 38(4), 325354. https://doi.org/10.1007/s11251-0089084-3 